\title{
PHYSIOLOGICAL JAUNDICE
}

BY

\author{
A. A. CUNNINGHAM \\ From the Kingston Hospital
}

(RECEIVED FOR PUBLICATION NOVEMBER 19, 1958)

Davidson, Merritt and Weech (1941), using the 'micro' method where blood was obtained from the heel, the usual amount collected being $0.5 \mathrm{ml}$., carried out a detailed study of bilirubin levels of 132 infants during the neonatal period. Correlated levels revealed that, at a concentration of $4-5 \mathrm{mg}$. \% per $100 \mathrm{ml}$. serum, approximately half of the infants had jaundice. They also found that there was a highly significant association between the level of bilirubin in serum from the umbilical cord and the subsequent intensity and duration of jaundice in the infant. Billing, Cole and Lathe (1954) studied normal newborn babies selected to provide a wide range of birth weights. Heel prick blood was collected with heparin or oxalate and 0.05 to $0.2 \mathrm{ml}$. of plasma was used in quantitative estimation by Van den Bergh diazo technique. It was found that the influence of birth weight on the amount of pigment extended through the range of birth weights from 3-9 lb. and was most fully extended among small infants where plasma concentration often rose to $12 \mathrm{mg}$. \% or above. They estimated that in certain circumstances the liver capacity to excrete pigment was reduced to $1-2 \%$ of normal. Meyer (1956) using venous samples of blood investigated serum bilirubin levels in 93 babies, of whom 46 were premature, who did not develop kernikterus. Babies under 2,000 g. (4 lb. 6 oz.) had levels rising on the sixth day, babies of $2,000-2,500 \mathrm{~g}$. levelling out, and babies over $2,500 \mathrm{~g}$. with falling levels on the sixth day.

The first stage in our research project was to find methods of bilirubin assay which could easily be applied to babies in the maternity unit. With the co-operation of Dr. D. Stark Murray, Kingston group pathologist, this was accomplished by $\mathrm{Mr}$. J. M. Daly, chief biochemical laboratory technician. The tests were primarily designed to meet our needs in the treatment of haemolytic disease.

* This report is part of a wider investigation covering the field of neonatal jaundice which was a prizewinning entry in the 1958 competition for research work sponsored by the South-West Metropolitan Regional Hospital Board.
Details of the Daly 'Macro' and 'Micro' Methods of Bilirubin Assay

The 'Macro' Method. This method was prompted by the need for quick and reliable estimations of serum bilirubin levels in cord blood from infants of rhesus negative mothers with antibodies. The method had to satisfy the following conditions: $(a)$ the colour had to be of sufficient intensity to give accurate absorptiometric readings over the range of $0 \cdot 5-5 \cdot 0 \mathrm{mg}$. \% which meant that a serum dilution factor greater than 1 in 10 was undesirable; $(b)$ the solution had to be free from turbidity; (c) sufficient solution had to be available for satisfactory readings; $(d)$ the method had to combine speed with simplicity and reliability.

Principle. Diazo reagent is added to the serum; simultaneous colour production and protein precipitation takes place with the addition of the alcohol/ether mixture. The proteins are then removed by centrifugation and the colour intensity of the clear supernatant fluid is measured photometrically (see Note 3 ).

REAGENTS. Absolute industrial spirit: ether: a mixture of equal volumes of each.

Van den Bergh diazo reagent: Solution A. Dissolve $1 \mathrm{~g}$. of sulphanilic acid in $15 \mathrm{ml}$. of concentrated $\mathrm{HCl}$. and make up to 11 . with water. Solution B. Dissolve $0.5 \mathrm{~g}$. of sodium nitrite in water and make up to $100 \mathrm{ml}$. Mix $10 \mathrm{ml}$. of Solution A with $0.3 \mathrm{ml}$. of Solution B.

(a) Direct Reaction. In a centrifuge tube place: (1) $0.5 \mathrm{ml}$. diazo reagent plus $0.5 \mathrm{ml}$. serum; (2) add $4 \mathrm{ml}$. of distilled water and mix; (3) transfer to a $1 \mathrm{~cm}$. cuvette and read at one minute and again at $\mathbf{1 5}$ minutes.

(b) INDIRECT REACTION. (Total bilirubin.) In a centrifuge tube place: (1) $0.5 \mathrm{ml}$. serum plus $0.5 \mathrm{ml}$. diazo reagent; (2) add $4 \mathrm{ml}$. of the alcohol/ether $(50 \% \mathrm{v} / \mathrm{v})$ mixture. Stopper with a rubber bung and mix well; (3) centrifuge for three minutes; (4) read in the colorimeter 10 minutes after the addition of the alcohol/ether reagent, using a wavelength of 540 millimicrons (Ilford filters 404 or 625); (5) read the result on a calibration curve.

Calibration Curve. Weigh out $20 \mathrm{mg}$. of dry bilirubin (B.D.H.) and dissolve in about $4 \mathrm{ml}$. of N/10 sodium hydroxide. Wash this into a $200 \mathrm{ml}$. volumetric flask with several flushes of water and make up to the mark. From this stock solution make up a series o 
standards containing $0 \cdot 5,1 \cdot 0,1 \cdot 5,2 \cdot 0,2 \cdot 5,3,4,5,6$, $7,8,9,10 \mathrm{mg}$. \% bilirubin by suitable dilution with saline. Each one of these standards is then put through Stages 1 and 2 for total bilirubin and the extinction values read after maximum colour has developed. This usually takes about half an hour. A calibration curve is then prepared from these data.

Notes. (1) The bilirubin standard must be made up fresh and the calibration curve prepared immediately. (2) After the addition of the alcohol/ether mixture the contents of the tube should be well mixed or a clear supernatant will not be obtained after centrifuging. (3) Ensure that the centrifuge used is of a type suitable for spinning inflammable mixtures of the alcohol/ether type. (4) If the bilirubin level exceeds $10 \mathrm{mg}$. \% dilute the serum with saline to bring it into this range. (See comparison chart, Fig. 1.)

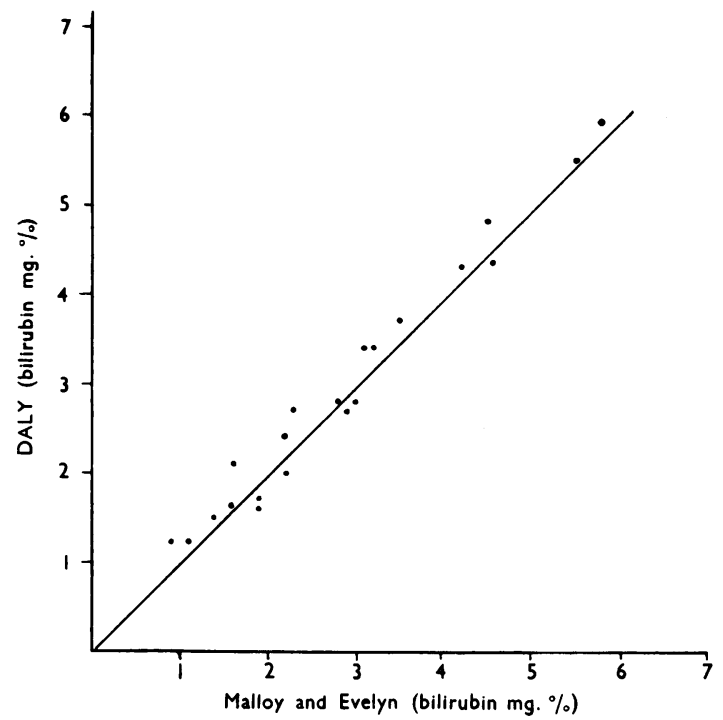

FIG. 1.-Comparison chart of parallel estimations of bilirubin (mg. \%)

The 'Micro' Method. This was devised as a rapid method of estimating the infant's bilirubin level at regular and perhaps frequent intervals using the minimal quantity of blood and involving the minimal inconvenience to the patient. The method requires only $0.1 \mathrm{ml}$. of blood and measures the bilirubin and its non-toxic conjugated components with a fair degree of accuracy. This is not set forward as a precision method of estimating bilirubin, but it does provide the necessary information quickly and gives reasonably accurate results in the range of $3-20 \mathrm{mg} . \%$ of serum bilirubin.

Principle. A micro-quantity of blood is added to a tube containing $0.85 \%$ sodium chloride solution. The tube is then centrifuged and the icterus of the serum measured photometrically.

METHOD: (a) TOTAL BiliRUBin. (1) $0.1 \mathrm{ml}$. of blood is obtained from a heel stab and washed into a tube containing $2.9 \mathrm{ml}$. of $0.85 \%$ saline. Care must be taken to avoid haemolysis. (In this laboratory a $1 \mathrm{~cm}$. diameter E.E.L. tube is used and has been found perfectly satisfactory in practice.) (2) Mix well by inversion and centrifuge for five minutes; (3) read in the colorimeter using a blue (Ilford 303) filter or, if a spectrophotometer is preferred, transfer the clear supernatant to a $\mathbf{1} \mathrm{cm}$. cuvette and read at $\mathbf{4 8 0}$ millimicrons using saline as blank; (4) read result against the calibration curve.

(b) Direct Bilirubin. (1) Take $2 \mathrm{ml}$. of the above supernatant fluid and pipette it into another $1 \mathrm{~cm}$. E.E.L. tube or cuvette; (2) add $1 \mathrm{ml}$. of diazo reagent; (3) mix and stand at room temperature for 15 minutes; (4) read in colorimeter using a green filter (Ilford 404) or if a spectrophotometer is preferred at 540 millimicrons; (5) read result against calibration curve.

Notes. (1) The blood must be collected with care as any trace of haemolysis affects the readings. Ether and not alcohol should be used to sterilize the skin. (2) If a spectrophotometer is available, the transmission at 578 millimicrons should be measured. This should not be lower than $90 \%$. (3) Lipochromes do not appear to interfere at the dilution used. (4) A haemoglobin estimation is always done at the same time.

Calibration Curve for Total Bilirubin. A sample of heparinised blood is obtained from a patient with obstructive jaundice (i.e. with a high direct component). Mix thoroughly and pour off a fraction of the sample into a centrifuge tube. Spin and estimate the bilirubin content according to the 'macro' method described. Place another fraction in a P.C.V. tube and estimate its value. This should be in the region of $50 \% \pm 2 \%$.

The curve is then prepared by taking $0.1,0.09$, $0.08 \mathrm{ml}$. etc. down to $0.01 \mathrm{ml}$. of the heparinised whole blood sample and making up the volume in each case to $0.1 \mathrm{ml}$. with a well mixed heparinised blood sample from an unjaundiced patient. These samples are washed into $2.9 \mathrm{ml}$. of saline and treated according to the Stages 1, 2, 3 and 4 as for total bilirubin. Plot a graph.

In this laboratory the original calibration curve was prepared from a sample of blood containing a serum bilirubin of $20 \mathrm{mg}$. \%, a haemoglobin of $102 \%$ and P.C.V. of $49 \%$. This curve has been repeatedly checked throughout the recorded series and found to be quite constant so that slight variations in haemoglobin and P.C.V. content do not appear to influence the result very greatly.

Calibration Curve for Direct Bilirubin. After reading the total bilirubin samples above, transfer $2 \mathrm{ml}$. of the supernatant fluids to $1 \mathrm{~cm}$. E.E.L. tubes or cuvettes and treat the samples according to Stages 2, 3, 4 and 5 as for direct bilirubin. Plot a graph.

\section{Present Investigation}

It was decided to investigate a sequence of 1,000 babies born in the maternity unit of Kingston Hospital from April 1, 1957, onwards, over a period of seven months. We eliminated from the investigation all babies of $2 \frac{1}{2} \mathrm{lb}$. and under, those suffering 
from haemolytic disease of the newborn and a few who did not live long enough to develop jaundice. The babies were visited daily and an estimate of the jaundice made clinically in daylight as far as possible. Bilirubin estimations were carried out at various stages in an effort to find the day of maximal staining. Table 1 gives a résumé of the results.

For control purposes, estimations were carried out on 50 babies of various weights on various days of life at a time when no clinical jaundice was detectable, even after pressing the skin in a good light. In $\mathbf{4 5}$ out of 50 cases, the total bilirubin was less than $3 \mathrm{mg} . \%$. In each of three cases the total was $3 \mathrm{mg}$. $\%$, in one case it was $3.5 \mathrm{mg} . \%$ and in another $4.5 \mathrm{mg}$. $\%$. This shows that there is a small error in clinical judgment. Lighting, texture of the skin and the high red cell count are factors which cause this difficulty of assessment.

In our series it was quite possible that cases of jaundice of a few hours' duration were missed, so it was decided that it would be more accurate to analyse only those cases of jaundice with a total bilirubin content of over $5 \mathrm{mg}$. \%. The results are shown graphically on the accompanying charts (Figs. 2 and 3) where bilirubin total and direct estimations are plotted against weight in pounds, with standard deviations in each group. Table 2 gives the percentage in each weight group in relation to the total number of babies in the survey.

It will be seen that there were 140 babies with a maximal total bilirubin over $5 \mathrm{mg} . \%=14 \%$ of total and of these there were 34 with maximal bilirubin over $10 \mathrm{mg}$. $\%=3.4 \%$ of total. Furthermore, it would appear that about $70 \%$ of babies weighing $4 \frac{1}{2} \mathrm{lb}$. or less at birth will develop maximal jaundice to a level of over $5 \mathrm{mg}$. $\%$ and about $30 \%$ to over $10 \mathrm{mg} . \%$. In addition, seven out of 63, i.e. approximately $11 \%$ of all premature babies will produce a maximal bilirubin percentage of $15 \mathrm{mg}$. \% or more and it is in this group that the danger of kernikterus arises.

Exchange transfusion is the only treatment we have to control the rise of bilirubin concentration, but this is a procedure fraught with considerable danger to small babies and it is difficult to decide at what level the procedure should be carried out or repeated.

Exchange transfusions were carried out in three cases in this series.

\section{Case Notes}

Case 1. J.A., a male twin (1), was born following antepartum haemorrhage with first loss six days prior to admission and quite heavy loss during the day of admission. The mother, aged 19 , had had three children (two miscarriages in two previous years at two to three months). J.A. cried in one minute and respirations were feebly established in two minutes. The baby weighed $3 \mathrm{lb} .11 \frac{1}{2} \mathrm{oz}$. when admitted to the Premature Baby Unit, and oxygen was given throughout the day. The mother's blood group was A Rh. + ve, baby's A Rh. + ve. On the second day at 5 a.m., the baby had a severe cyanotic attack. Intragastric oxygen was given with coramine and lobeline about half an hour later as respirations were intermittent and the heart beat extremely weak. Penicillin and streptomycin were given intramuscularly. On the third day, the baby's general condition was still poor and tent oxygen was continued. Bilirubin total $13.5 \mathrm{mg}$. \%, direct $3.5 \mathrm{mg}$. \%. On the fourth day his condition had improved slightly. Bilirubin total of $12 \mathrm{mg}$. $\%$, direct $4.0 \mathrm{mg}$. \%. On the fifth day his general condition was fair, but jaundice was very marked. Total bilirubin $18.0 \mathrm{mg}$. $\%$, direct $7.0 \mathrm{mg}$. $\%$.

TABLE 2

CASES WITH MAXIMAL TOTAL BILIRUBIN

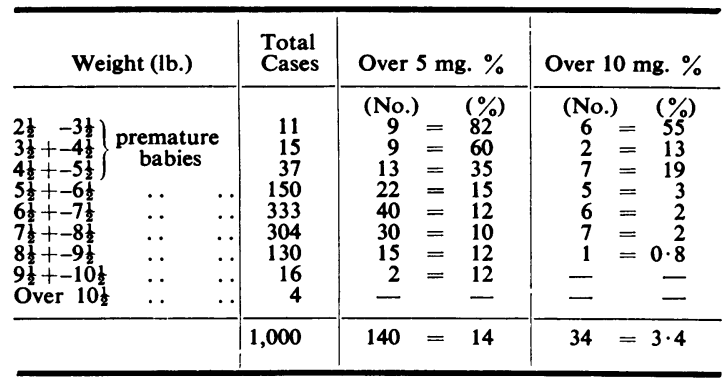

TABLE 1

JAUNDICED BABIES : MAXIMAL TOTAL BILIRUBIN (MG. \%)

\begin{tabular}{|c|c|c|c|c|c|c|c|c|}
\hline Weight (lb.) & & All Babies & $5-3$ & $10-5$ & $15-10$ & $20-15$ & Over 20 & Total \\
\hline \multirow[t]{2}{*}{$\begin{array}{r}2 \frac{1}{2}+-3 \frac{1}{2} \\
3 \frac{1}{2}+-4 \frac{1}{2} \\
4 \frac{1}{2}+-5 \frac{1}{2} \\
5 \frac{1}{2}+-6 \frac{1}{2} \\
6 \frac{1}{2}+-7 \frac{1}{2} \\
7 \frac{1}{2}+-8 \frac{1}{2} \\
8 \frac{1}{2}+-9 \frac{1}{2} \\
9 \frac{1}{2}+-10 \frac{1}{2} \\
10 \frac{1}{2}+-11 \frac{1}{2}\end{array}$} & $\begin{array}{l}\ldots \\
\ldots \\
\ldots \\
\ldots \\
\cdots \\
\ldots \\
\cdots\end{array}$ & $\begin{array}{r}11 \\
15 \\
37 \\
150 \\
333 \\
304 \\
130 \\
16 \\
4\end{array}$ & $\begin{array}{r}1 \\
2 \\
5 \\
23 \\
63 \\
54 \\
8 \\
1 \\
-\end{array}$ & $\begin{array}{r}3 \\
7 \\
6 \\
17 \\
34 \\
23 \\
14 \\
2 \\
-\end{array}$ & $\begin{array}{l}4 \\
1 \\
7 \\
5 \\
6 \\
7 \\
1 \\
-\end{array}$ & $\begin{array}{l}1 \\
1 \\
= \\
= \\
= \\
-\end{array}$ & $\begin{array}{l}1 \\
= \\
= \\
-\end{array}$ & $\begin{array}{r}10 \\
11 \\
18 \\
45 \\
103 \\
84 \\
23 \\
3 \\
-\end{array}$ \\
\hline & & 1,000 & 157 & 106 & 31 & 2 & 1 & 297 \\
\hline
\end{tabular}




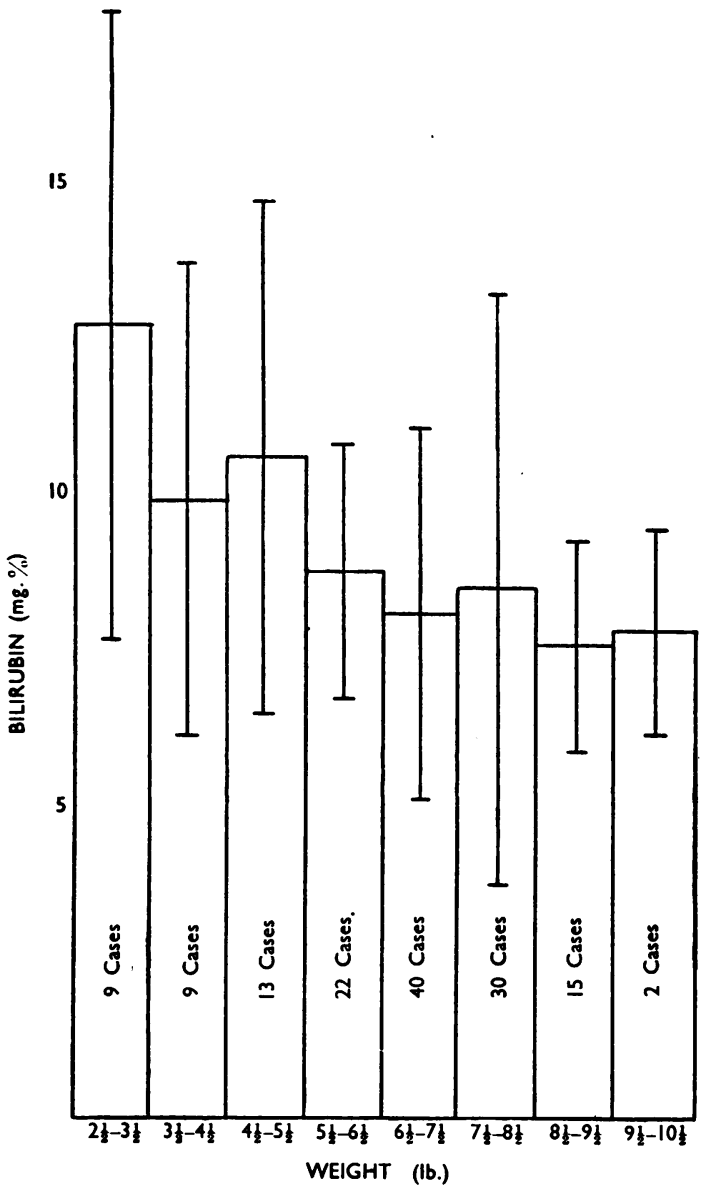

Total bilirubin:

in babies with total bilirubin over $5 \mathrm{mg}$. $\%$.

\begin{tabular}{ccc} 
lb. & Average & S.D. \\
\hline $2 \frac{1}{2}-3 \frac{1}{2}$ & $12 \cdot 7$ & $5 \cdot 1$ \\
\hline $3 \frac{1}{2}-4 \frac{1}{2}$ & $9 \cdot 8$ & $3 \cdot 8$ \\
\hline $4 \frac{1}{2}-5 \frac{1}{2}$ & $10 \cdot 6$ & $4 \cdot 0$ \\
\hline $5 \frac{1}{2}-6 \frac{1}{2}$ & $8 \cdot 7$ & $2 \cdot 0$ \\
\hline$\frac{1}{2}-7 \frac{1}{2}$ & $8 \cdot 0$ & $2 \cdot 9$ \\
$7 \frac{1}{2}-8 \frac{1}{2}$ & $8 \cdot 4$ & $4 \cdot 6$ \\
$8 \frac{1}{2}-9 \frac{1}{2}$ & $7 \cdot 6$ & $1 \cdot 7$ \\
$9 \frac{1}{2}-10 \frac{1}{2}$ & $7 \cdot 8$ & $1 \cdot 7$
\end{tabular}

* The limits of one standard deviation are shown as a vertical line.

Fig. 2. - Total bilirubin estimation plotted against weight in pounds, with standard deviation in each group.

On the evening of the fifth day when the jaundice appeared to be very severe and the baby became listless and ill, it was decided to carry out an exchange transfusion. After $90 \mathrm{ml}$. the child's condition was so poor that transfusion was discontinued. The child's shocked condition did not, however, respond to resuscitative measures, and the child died about $\mathbf{4 0}$ minutes after the transfusion was stopped; at autopsy there was marked cerebral oedema, but no evidence of kernikterus.

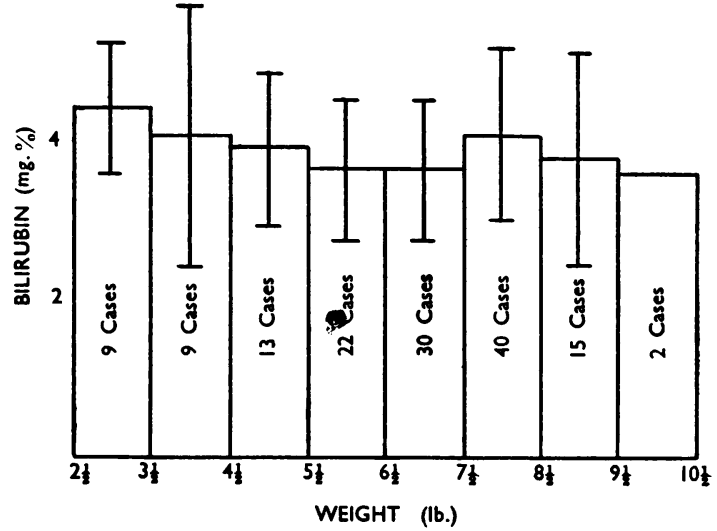

F,G. 3.-Relationship between birthweight and maximal-direct bilirubin (linked with maximal total). The limits of one standard deviation are shown as a vertical line.

Direct bilirubin (conjugated):

in babies with total bilirubin over $5.0 \mathrm{mg}$. $\%$.

$\begin{array}{rccc}\text { lb. } & \text { Cases } & \text { Mean } & \text { One S.D. } \\ 2 \frac{1}{2}-3 \frac{1}{2} & 9 & 4 \cdot 5 & 0 \cdot 8 \\ 3 \frac{1}{2}-4 \frac{1}{2} & 9 & 4 \cdot 1 & 1 \cdot 6 \\ 4 \frac{1}{2}-5 \frac{1}{2} & 13 & 4 \cdot 0 & 1 \cdot 0 \\ 5 \frac{1}{2}-6 \frac{1}{2} & 22 & 3 \cdot 7 & 0 \cdot 9 \\ 6 \frac{1}{2}-7 \frac{1}{2} & 40 & 3 \cdot 7 & 0 \cdot 9 \\ 7 \frac{1}{2}-8 \frac{1}{2} & 30 & 4 \cdot 1 & 1 \cdot 1 \\ 8 \frac{1}{2}-9 \frac{1}{2} & 15 & 3 \cdot 8 & 1 \cdot 3 \\ 9 \frac{1}{2}-10 \frac{1}{2} & 2 & 3 \cdot 6 & - \\ & 140 & & \end{array}$

FIG. 3.-Direct bilirubin estimation plotted against weight in pounds with standard deviation in each group.

Case 2. D.A., a male twin (2), brother of the above twin, was born by breech delivery. He cried in one minute, and respiration was established in two. Birth weight was $3 \mathrm{lb} .3 \mathrm{oz}$. Both legs were discoloured and oedematous. His blood group was A Rh. +ve. On the first day the child passed a melaena stool on two occasions. Vitamin K $2.5 \mathrm{mg}$. was given intramuscularly. On the second day there were several melaena stools. Jaundice at 24 hours. On the third day the baby was deeply jaundiced. Total bilirubin $13.5 \mathrm{mg}$. \%, direct $3.5 \mathrm{mg}$. \%. Exchange transfusions was carried out in the evening of the third day. Intramuscular digoxin $0.0625 \mathrm{mg}$. was given before transfusion. The bilirubin total fell from $15 \mathrm{mg}$. \% at the onset to $9 \mathrm{mg}$. \% towards the end of the transfusion. The total exchange was $240 \mathrm{ml}$. in and $243 \mathrm{ml}$. out. The child's condition was very poor throughout the night following the transfusion and there were grunting respirations all the time. He had improved slightly on the fourth day. Bilirubin total $12.0 \mathrm{mg}$. $\%$, direct $4.0 \mathrm{mg} . \%$. On the fifth day jaundice again was deep. Bilirubin total $22.0 \mathrm{mg}$. $\%$, direct $8.0 \mathrm{mg} . \%$. A second exchange transfusion was started, but after $20 \mathrm{ml}$. great difficulty was experienced with clotting in the catheter and it was decided to discontinue the operation. Dextrose saline, $50 \mathrm{ml}$., was given intravenously. 
Jaundice was still very deep on the sixth day. There were no signs of kernikterus in the central nervous system. Bilirubin total $26.0 \mathrm{mg}$. \%, direct $6.0 \mathrm{mg}$. $\%$. On the seventh day jaundice was still deep. Again there were no signs of kernikterus. Bilirubin total $24.0 \mathrm{mg} . \%$, direct $8.0 \mathrm{mg}$. $\%$. On the ninth day bilirubin total $16.0 \mathrm{mg}$. $\%$, direct $4.0 \mathrm{mg}$. $\%$, and on the fifteenth day bilirubin total $4.5 \mathrm{mg}$. $\%$, direct $2.0 \mathrm{mg}$. $\%$.

This baby made good progress in the neonatal period, developed anaemia on the thirty-third day of life and was given $75 \mathrm{ml}$. of fresh blood. He continued to make good progress, gained weight, and since then has developed into a normal healthy baby.

Case 3. J.D., male. The mother was admitted with severe antepartum haemorrhage. There was a normal vertex delivery, and the birth weight was $3 \mathrm{lb} .3 \mathrm{oz}$. He cried weakly in one minute, and then respiration became grunting in character. His condition improved after intragastric oxygen for half an hour. The child was placed in an oxygen tent. There was a melaena stool on the first day, and again on the second with fresh blood. Synkavit, $1 \mathrm{mg}$., was given intramuscularly. Jaundice was noticed at 30 hours. On the third day jaundice increased. Bilirubin total (a.m.) $9.0 \mathrm{mg}$. \%, direct $4.0 \mathrm{mg} . \%$. Stools contained a large amount of fresh blood. By evening the bilirubin total was $11.5 \mathrm{mg} . \%$, direct $4.0 \mathrm{mg}$. $\%$. In spite of the considerable amount of fresh blood in the stools, the haemoglobin remained high. It was decided to carry out a small exchange transfusion using very fresh blood, primarily with the object of treating the haemorrhagic disease yet also to control the bilirubin concentration. The transfusion was completed in 1 hour $(110 \mathrm{ml}$. in and $110 \mathrm{ml}$. out) by which time the baby's condition showed signs of deterioration. The respirations were shallow and grunting and there were some twitching jerking movements which responded quickly to chloral hydrate sedation. On the fourth day a dark melaena stool was passed on two occasions. Bilirubin total $10 \mathrm{mg}$. \%, direct $3.5 \mathrm{mg} . \%$. On the fifth day his general condition was much improved. Bilirubin total $10.0 \mathrm{mg}$. $\%$, direct $4.0 \mathrm{mg}$. \%. The improvement continued on the sixth day. Melaena stool. Bilirubin total $16.5 \mathrm{mg}$. \%, direct $4.0 \mathrm{mg}$. \%. On the seventh day bilirubin total $15.0 \mathrm{mg}$. $\%$, direct $7.0 \mathrm{mg}$. $\%$.

The jaundice lasted in all about 13 days. The lowest weight was $2 \mathrm{lb}$. $91 \mathrm{oz}$. on the fourteenth day, and from then onwards progress was steady and uneventful, apart from the development of anaemia in the sixth week of life. This case emphasizes the value of a small exchange transfusion, using fresh blood, in the treatment of haemorrhagic disease where the haemoglobin is high and the baby very small.

The quick methods of bilirubin assay were of particular value in following up the jaundice in these three cases. It is interesting to speculate on the danger of bilirubin, but one feels that in the development of kernikterus in premature babies there are probably other factors as well as the increased level of bilirubin.

It is also to be noted that a small percentage of babies weighing over $5 \frac{1}{2} \mathrm{lb}$. will develop comparatively high levels of jaundice. The percentage appears to vary very little with birth weight in this group or with period of gestation and it is rather remarkable that the figures for, say, $8 \frac{1}{2}-\mathrm{lb}$. babies are little different from those of, say, 6-lb. babies.

The incidence of jaundice, especially as it appeared to be similar in the various weight groups over $5 \frac{1}{2} \mathrm{lb}$., suggested that there might be some cause which operated at all weights in non-premature babies. Rhesus incompatibility was excluded in all cases as routine, but ABO or other blood group incompatibility was much more difficult to recognize. Severe cases of $\mathrm{ABO}$ haemolytic disease can generally be diagnosed clinically even without the help of laboratory aids, but mild cases present a problem. Unlike rhesus disease, $\mathrm{ABO}$ incompatibility cannot be anticipated by antenatal testing. However, since the work of Boorman, Dodd and Trinick (1949) more cases of $\mathrm{ABO}$ haemolytic disease have been recognized. Valentine (1958) selected from 1,000 unselected live births all babies showing jaundice in the first 24 hours of life. Of 21 so investigated, seven were cases of rhesus haemolytic disease. The jaundice of the remaining 14 he considered to be due to ABO haemolytic disease. He concluded that ABO haemolytic disease can occur in a clinically recognized form as often as once in 71 births and may arise in $7 \%$ of $\mathrm{AB}$ incompatible mother/child pairs, i.e. three times as commonly as rhesus haemolytic disease.

In this series, we had 24 cases where jaundice was detected about 24 hours after birth or less. The mother and baby blood groups are shown in Tables 3 and 4.

TABLE 3

BABIES WITH JAUNDICE 24 HR. OR LESS AFTER BIRTH: 24 PAIRS

\begin{tabular}{|c|c|c|c|c|c|c|c|c|c|c|c|}
\hline $\begin{array}{c}\text { Blood Group : } \\
\text { Mother's } \\
\text { Baby's }\end{array}$ & . & $\begin{array}{l}\mathbf{O} \\
\mathbf{A}\end{array}$ & $\begin{array}{l}\mathbf{O} \\
\mathbf{B}\end{array}$ & $\begin{array}{l}\mathrm{O} \\
\mathrm{O}\end{array}$ & $\begin{array}{l}\mathbf{A} \\
\mathbf{A}\end{array}$ & $\begin{array}{l}\mathbf{A} \\
\mathbf{O}\end{array}$ & $\stackrel{A}{A B}$ & $\begin{array}{l}\text { B } \\
\text { O }\end{array}$ & $\begin{array}{l}\mathbf{A} \\
\mathbf{B}\end{array}$ & $\begin{array}{l}\text { B } \\
?\end{array}$ & $\begin{array}{l}\mathrm{O} \\
?\end{array}$ \\
\hline Totals & .. & 4 & 1 & 7 & 6 & 1 & 1 & 1 & 1 & 1 & 1 \\
\hline
\end{tabular}

TABLE 4

ABO INCOMPATIBLE PAIRS WITH MOTHER'S BLOOD GROUP O JAUNDICE 24 HR. OR LESS AFTER BIRTH: 5 PAIRS

\begin{tabular}{|c|c|c|c|c|c|c|}
\hline $\begin{array}{c}\text { Blood Group : } \\
\text { Mother's } \\
\text { Baby's }\end{array}$ & $\begin{array}{l}\cdots \\
\cdots\end{array}$ & $\begin{array}{l}\text { O } \\
\text { B }\end{array}$ & $\underset{\mathrm{A}}{\mathrm{O}}$ & $\begin{array}{l}\mathbf{O} \\
\mathbf{A}\end{array}$ & $\begin{array}{l}\text { O } \\
\text { A }\end{array}$ & $\begin{array}{l}\mathbf{O} \\
\mathbf{A}\end{array}$ \\
\hline Baby's weight (lb. oz.) & .. & $4 \cdot 13$ & $6 \cdot 3 \frac{1}{2}$ & $7 \cdot 3$ & $7 \cdot 13$ & $8 \cdot 13$ \\
\hline Maximal bilirubin (mg. \%) & . & $15 \cdot 0$ & $7 \cdot 5$ & $7 \cdot 5$ & $5 \cdot 5$ & $12 \cdot 0$ \\
\hline
\end{tabular}


We then surveyed those cases of physiological jaundice where the maximal bilirubin was over $10 \mathrm{mg} . \%$ (34 in all) (Tables 5 and 6).

TABLE 5

ABO MOTHER/CHILD GROUPS

BABIES WITH MAXIMAL BILIRUBIN OVER 10 MG. \%: 34 PAIRS

\begin{tabular}{ccc|c|c|c|c|c|c|c|c}
\hline $\begin{array}{c}\text { Blood Group : } \\
\text { Mother's } \\
\text { Baby's }\end{array}$ &.. &.. & $\mathbf{O}$ & $\mathbf{O}$ & $\mathbf{O}$ & $\mathbf{A}$ & $\mathbf{A}$ & $\mathbf{B}$ & $\mathbf{A}$ & $\mathbf{A}$ \\
\hline Total &.. &.. & $\mathbf{7}$ & $\mathbf{1}$ & $\mathbf{1 0}$ & $\mathbf{1 2}$ & $\mathbf{1}$ & $\mathbf{1}$ & $\mathbf{1}$ & $\mathbf{1}$ \\
\hline
\end{tabular}

TABLE 6

ABO INCOMPATIBLE MOTHER/CHILD PAIRS WITH MOTHER'S GROUP O: 8 PAIRS

\begin{tabular}{|c|c|c|c|c|c|c|c|c|c|c|}
\hline $\begin{array}{c}\text { Blood Group : } \\
\text { Mother's } \\
\text { Baby's }\end{array}$ & $\because$. & $\begin{array}{l}\cdots \\
\cdots\end{array}$ & $\begin{array}{l}\mathbf{O} \\
\mathbf{A}\end{array}$ & $\begin{array}{l}\mathbf{O} \\
\mathbf{A}\end{array}$ & $\underset{\mathbf{A}}{\mathbf{O}}$ & $\underset{\mathbf{A}}{\mathbf{O}}$ & $\begin{array}{l}\mathbf{O} \\
\mathbf{A}\end{array}$ & $\begin{array}{l}\mathbf{O} \\
\mathbf{A}\end{array}$ & $\underset{\text { B }}{\mathbf{O}}$ & $\begin{array}{l}\mathbf{O} \\
\mathbf{A}\end{array}$ \\
\hline \multicolumn{3}{|c|}{ Baby's weight (lb. oz.) } & $\overline{5 \cdot 4}$ & $\overline{7 \cdot 13}$ & $7 \cdot 9$ & $\overline{5 \cdot 5}$ & $\overline{6 \cdot 15 \frac{1}{2}}$ & $\overline{3 \cdot 3}$ & $\overline{4 \cdot 13}$ & $\overline{8 \cdot 13}$ \\
\hline \multicolumn{3}{|c|}{ Maximal bilirubin (mg. \%) } & $\overline{12 \cdot 0}$ & $\overline{10 \cdot 5}$ & $\overline{12 \cdot 5}$ & $\overline{15 \cdot 0}$ & $13 \cdot 5$ & $\overline{16 \cdot 5}$ & $\overline{15 \cdot 0}$ & $\overline{12 \cdot 0}$ \\
\hline
\end{tabular}

In this short series, the babies of three of the OA pairs and that of the $\mathrm{OB}$ pair were premature. We did not have the facilities for carrying out extensive blood type grouping such as that which Valentine used, but if one excludes prematurity the number of cases of $\mathrm{ABO}$ haemolytic disease in our series must have been very limited, if indeed any cases existed at all. The babies from the ABO incompatible mother/child pairs were clinically no different from those where there was $\mathrm{ABO}$ compatibility.

The incidence of group A persons in the general population in this part of southern England is slightly higher than that for the British Isles as a whole, so if $\mathrm{ABO}$ haemolytic disease is as common as Valentine suggests there should be more evidence of it in a series of this kind. Our experience, therefore, does not support Valentine's work.

Apart from prematurity, we have not been able to separate any other cause for so-called 'physiological jaundice'. Vitamin $\mathrm{K}$ was given sparingly in doses of 1-2.5 mg., one dose only in each case, to premature babies and to a trivial number of other babies after complicated obstetric procedures. We did not consider vitamin $\mathrm{K}$ in this dosage to be a factor. There was no evidence of syphilis or sepsis, or blood disease in any of our cases.

\section{Cord Blood Estimations}

In a further series of babies, an effort was made to correlate the level of cord bilirubin with subsequent jaundice, but in practice this was most difficult and quite unrewarding. It was quite impossible to get a succession of cases, for complicated obstetric procedures, quick removal of the placenta, concentrated obstetric work, etc., made the collection of samples extremely difficult, and at times impossible. It was also disturbing to find that certain samples taken by skilled operators soon after birth were unsatisfactory because of slight haemolysis. This haemolysis, presumably due to enzyme action, occurred between one and 10 minutes after birth. The result of the investigation, therefore, applied to random samples taken as and when convenient.

Table 7 shows the correlation between weight and cord blood bilirubin estimations in 80 babies who did not subsequently develop clinical jaundice:

TABLE 7

CORD BLOOD TOTAL BILIRUBIN ESTIMATION IN 80 BABIES WITHOUT SUBSEQUENT CLINICAL JAUNDICE

\begin{tabular}{|c|c|c|c|}
\hline Weight (lb.) & $\begin{array}{l}\text { Up to and } \\
\text { including } \\
1.5 \mathrm{mg} . \%\end{array}$ & $\begin{array}{l}\text { Over } 1.5 \text { to } \\
2.0 \mathrm{mg} . \%\end{array}$ & $\begin{array}{l}\text { Over } 2.0 \text { to } \\
2.5 \mathrm{mg} . \%\end{array}$ \\
\hline $\begin{array}{lll}\text { Over } 5 \frac{1}{2} \text { to } 6 \frac{1}{2} & \ldots \\
\text { Over } 6 \frac{1}{2} \text { to } 7 \frac{1}{2} & \ldots \\
\text { Over } 7 \frac{1}{2} \text { to } 8 \frac{1}{2} & \ldots \\
\text { Over } 8 \frac{1}{2} \text { to } 9 \frac{1}{2} & \ldots \\
\text { Over } 9 \frac{1}{2} \text { to } 10 \frac{1}{2} & \ldots\end{array}$ & $\begin{array}{c}\text { (no.) } \\
6 \\
16 \\
10 \\
11 \\
3\end{array}$ & $\begin{array}{c}\text { (no.) } \\
1 \\
10 \\
8 \\
3 \\
-\end{array}$ & $\begin{array}{c}\text { (no.) } \\
1 \\
3 \\
6 \\
2 \\
-\end{array}$ \\
\hline Total (80) & $46=57 \cdot 5 \%$ & $22=27 \cdot 5 \%$ & $12=15 \%$ \\
\hline
\end{tabular}

Table 8 shows the cord blood total bilirubin estimation in 39 babies who subsequently developed clinical jaundice:

Of the babies without clinical jaundice all had a total bilirubin in the cord blood of $2.5 \mathrm{mg}$. \% or less and of this total, $57.5 \%$ had a total cord blood bilirubin of $1.5 \mathrm{mg} . \%$ or less. Of those with clinical jaundice, $38.4 \%$ had a cord bilirubin over

TABLE 8

CORD BLOOD TOTAL BILIRUBIN ESTIMATION IN 39 BABIES WHO LATER DEVELOPED CLINICAL JAUNDICE

\begin{tabular}{|c|c|c|c|c|c|}
\hline Weight (lb.) & $\begin{array}{l}\text { Up to and including } \\
1.5 \mathrm{mg} . \%\end{array}$ & Over $1.5-2.0 \mathrm{mg} . \%$ & Over $2 \cdot 0-2 \cdot 5 \mathrm{mg} . \%$ & Over $2.5-3.0 \mathrm{mg} . \%$ & Over $3.0 \mathrm{mg} . \%$ \\
\hline $\begin{array}{l}\text { Over } 5 \frac{1}{2} \text { to } 6 \frac{1}{2} \ldots \\
\text { Over } 6 \frac{1}{2} \text { to } 7 \frac{1}{2} \cdots \\
\text { Over } 7 \frac{1}{2} \text { to } 8 \frac{1}{2} \cdots \\
\text { Over } 8 \frac{1}{2} \text { to } 9 \frac{1}{2} \cdots \\
\text { Over } 9 \frac{1}{2} \text { to } 10 \frac{1}{2}\end{array}$ & $\begin{array}{l}2 \\
= \\
-\end{array}$ & $\begin{array}{l}2 \\
3 \\
3 \\
2 \\
\end{array}$ & $\begin{array}{l}3 \\
4 \\
3 \\
2 \\
\end{array}$ & $\begin{array}{l}4 \\
3 \\
3 \\
1 \\
1 \\
1\end{array}$ & $\begin{array}{l}1 \\
1 \\
1 \\
\end{array}$ \\
\hline Total (39) & $2=5 \cdot 1 \%$ & $10=25 \cdot 6 \%$ & $12=30 \cdot 8 \%$ & $12=30 \cdot 8 \%$ & $3=7 \cdot 6 \%$ \\
\hline
\end{tabular}


TABLE 9

\begin{tabular}{|c|c|c|c|c|c|c|c|c|c|c|c|c|c|c|}
\hline \multirow[t]{2}{*}{ Sex } & \multirow{2}{*}{$\frac{\text { Weight }}{\text { lb. oz. }}$} & \multirow{2}{*}{$\frac{\text { Blood }}{\text { Mother }}$} & \multirow{2}{*}{$\frac{\text { Group }^{*}}{\text { Baby }}$} & \multicolumn{2}{|c|}{$\begin{array}{l}\text { Cord Bilirubin } \\
\text { (mg. \%) }\end{array}$} & \multicolumn{9}{|c|}{ Day of Maximal Total Bilirubin (mg. \%) $\dagger$} \\
\hline & & & & Total & Direct & 2 & 3 & 4 & 5 & 6 & 7 & 8 & 9 & 10 \\
\hline $\mathbf{M}$ & 79 & $\mathbf{A}+\mathbf{v e}$ & $A+v e$ & 1.6 & $0 \cdot 3$ & - & - & $7 \cdot 5$ & $7 \cdot 5$ & - & $\begin{array}{r}9 \cdot 0 \\
(4 \cdot 0)\end{array}$ & - & 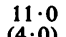 & 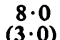 \\
\hline $\mathbf{F}$ & 513 & $\mathbf{O}+\mathbf{v e}$ & $\mathbf{O}+\mathbf{v e}$ & $2 \cdot 5$ & 0.6 & 二 & $\overline{7 \cdot 5}$ & 10.5 & 9.0 & 二 & - & $\begin{array}{r}7.5 \\
(4.0)\end{array}$ & $=$ & $=$ \\
\hline $\mathbf{F}$ & 514 & $A+v e$ & $A+v e$ & $1 \cdot 3$ & 0.6 & $\overline{6 \cdot 5}$ & - & $\begin{array}{l}4 \cdot 3) \\
3 \cdot 0\end{array}$ & $\begin{array}{r}3.37 \\
3.0\end{array}$ & 二 & 二 & $\begin{array}{l}4.07 \\
7.5\end{array}$ & 二 & 二 \\
\hline $\mathbf{M}$ & 79 & $\mathrm{O}-\mathrm{ve}$ & A-ve & $3 \cdot 4$ & 0.0 & $4 \cdot 5$ & 二 & $4 \cdot 5$ & (1) & 二 & 二 & - & 二 & - \\
\hline $\mathbf{M}$ & 82 & $\mathbf{B}+\mathbf{v e}$ & $\mathrm{O}+\mathrm{ve}$ & $1 \cdot 6$ & 0.0 & $3 \cdot 0$ & $\overline{7 \cdot 5}$ & $(2 \cdot 0)$ & 二 & 二 & 二 & 二 & 二 & 二 \\
\hline $\mathbf{M}$ & 713 & $A+v e$ & $A+v e$ & $3 \cdot 0$ & 0.5 & (0.0) & $(2 \cdot)$ & 二 & $\overline{4 \cdot 5}$ & 二 & 二 & 二 & 二 & - \\
\hline $\mathbf{M}$ & 712 & $A+v e$ & $A+v e$ & $3 \cdot 0$ & $0 \cdot 75$ & 二 & $\overline{3 \cdot 0}$ & 二 & $(-3)$ & $\overline{6 \cdot 0}$ & $\overline{5 \cdot 0}$ & 二 & 二 & $\bar{z}$ \\
\hline $\mathbf{M}$ & 78 & $\mathbf{A}+\mathbf{v e}$ & B + ve & $2 \cdot 7$ & 0.75 & 二 & $7 \cdot 5$ & $7 \cdot 5$ & $7 \cdot 5$ & - & - & - & - & - \\
\hline $\mathbf{M}$ & 610 & $\mathrm{O}+\mathrm{ve}$ & $A-\mathbf{v e}$ & $3 \cdot 6$ & $1 \cdot 0$ & $3 \cdot 5$ & (2.) & $\begin{array}{l}(2 \cdot 3) \\
4.5\end{array}$ & $(2 \cdot 3)$ & 二 & 三 & - & 二 & 二 \\
\hline & & & & & & $(0 \cdot 5)$ & - & $(1 \cdot 5)$ & - & - & - & - & - & - \\
\hline
\end{tabular}

* Positive and negative signs refer to $\mathrm{Rh}+\mathrm{ve}$ and $\mathrm{Rh}-\mathrm{ve}$

$\dagger$ (Direct component in parenthesis)

$2.5 \mathrm{mg} . \%$ and only a small percentage had a cord bilirubin over $3 \mathrm{mg}$. $\%$. The highest figure in the series was a cord blood bilirubin of $3.6 \mathrm{mg}$. $\%$ (direct $1.0 \mathrm{mg} . \%$ )-a male child weighing $6 \mathrm{lb} .10 \mathrm{oz}$. who subsequently developed a mild degree of jaundice only, reaching a maximal total bilirubin of $4.5 \mathrm{mg}$. \% (direct $1.5 \mathrm{mg}$. \%) on the fifth day. The other babies with a cord blood bilirubin of over $3 \mathrm{mg}$. \% all developed a comparatively mild degree of jaundice around $5 \mathrm{mg}$. \% at the maximum. The great variety in results is shown in Table 9 by some examples.

This short investigation, carried out under great difficulty (and not very popular in the obstetric department) showed that estimations of cord bilirubin were of very little value in forecasting the subsequent development of jaundice. We could not find the correlation which other workers have reported.

\section{Summary}

A series of 1,000 consecutive babies born in the maternity unit of Kingston Hospital was studied with particular reference to the incidence of so-called 'physiological jaundice'. The series did not include cases of diagnosable haemolytic disease, premature babies under $2 \frac{1}{2} \mathrm{lb}$. in weight and those babies who died before jaundice could be determined; $14 \%$ of the babies developed a maximal bilirubin over $5 \mathrm{mg}$. \% and of the total $3.4 \%$ developed a maximal total bilirubin over $10 \mathrm{mg}$. \%

Of the premature babies, 63 in all, 11 developed a maximal bilirubin concentration of $15 \mathrm{mg}$. \% or more; three of these had exchange transfusion, one of whom died, but the other two made a good recovery and are normal healthy children.
The incidence and severity of so-called physiological jaundice is most marked in premature babies and is presumably associated with immaturity of liver function; in about $10 \%$ of these babies there is some risk of the development of kernikterus. In babies over $5 \frac{1}{2} \mathrm{lb}$. in weight at birth, about $2 \%$ developed jaundice with a maximal bilirubin level over $10 \mathrm{mg}$. \%, but there did not appear to be any danger of kernikterus in these cases. Contrary to the work of Valentine (1958), we did not find any evidence to justify a diagnosis of ABO haemolytic disease as a causative factor, even in those babies who developed jaundice within 24 hours of birth.

In a second series of 119 babies, taken at random (80 without clinical jaundice and 39 with clinical jaundice) no correlation of value could be found when cord blood estimations were linked with the development of subsequent jaundice.

I should like to acknowledge the help and co-operation received from Dr. D. Stark Murray, group pathologist, and Dr. B. Meade, consultant biochemist, of the Kingston Group Laboratory, and Dr. A. F. Huston, assistant paediatrician. I must particularly thank Mr. G. Gray and Mr. J. M. Daly, senior laboratory technicians, who collected and tested most of the blood samples, also Miss J. MacIntyre, Matron, Miss C. M. Bowen, superintendent midwife, and many sisters and nurses from the Maternity Unit, without whose devoted care, nursing skill and goodwill, an investigation of this type would be of no avail.

\section{REFERENCES}

Billing, B. H., Cole, P. G. and Lathe, G. (1954). Brit. med. J., 2, Boorman, K. E., Dodd, B. E. and Trinick, R. H. (1949). Lancet, 1,1088 .

Davidson, L. T., Merritt, K. K. and Weech, A. A. (1941). Amer. J. Dis. Child., 61, 958.

Meyer, T. C. (1956). Arch. Dis. Childh., 31, 75.

Valentine, G. H. (1958). Ibid., 33, 185. 